\title{
Toplumsal Değerler Çerçevesinde Kamu Hizmetleri ve Profesyonel Polislik
}

\author{
DOI: 10.26466/opus.721357
}

*

\author{
Ozan Kavsirac1 * \\ * Dr. Öğretim Üyesi, Polis Akademisi Başkanlığı, Ankara / Türkiye \\ E-Posta: ozankavsiraci@gmail.com \\ ORCID: $\underline{0000-0001-6351-3725}$
}

\section{Öz}

Insanlar toplumların birer ferdi olmakla beraber, toplumsal hayatın vazgeçilmez parçası olan mesleki faaliyetlerin de yürütücüsüdürler. Toplumları ve devletleri etkileyen krizlerin temelinde kişisel değerler çerçevesinde ahlaki karar alma ve ahlaki davranışlar göstermede yaşanan eksikler yatmaktadır. Bu eksikliklerin yaşanmaması için hizmetlerin, ahlaki bir yönetim iklimi içeresinde yerine getirilmesi gerekmektedir. Bu yönetim anlayışını hâkim kılma noktasında da etik ilke ve değerler karşımıza çıkmaktadır. Toplumsal hayata yön veren ve insan davranışlarım harekete geçiren değerler ve ilkeler, mesleki faaliyetlerin yürütülmesinde de önemli rol oynamaktadır. Değerler, insanların yaşam biçimlerini hem duygusal hem de davranışsal olarak etkilemektedir ve mesleklere ilişkin etik ilkelerin temelini oluşturmaktadır. Kamu hizmetleri, kamu yararı amacı güdülerek yerine getirilen faaliyetlerdir. Bu kapsamda kamu hizmetini icra eden kişiler de toplum için ortak faydayı öncelemek zorundadırlar. Kamu hizmetlerinin bu niteliğinden dolayı hizmetlerin ahlaki bir faaliyet olarak görülmesi önem arz etmektedir. Etik yönetim, sadece yasalara uygun olmayan davranışları önlemekle sinırlandırılmamalıdır. Etik yönetim ayn zamanda etik davranışlar desteklemeyi amaçlamalıdır. Kamu yönetiminin bir parçası olan güvenlik hizmetleri, salt savunma veya saldırı amaçlı değil, insanların güvenliği ve huzurunu amaçlayan bir hizmet sektörüdür. Güvenlik hizmetlerinin temel hak ve özgürlüklerin kullanılması üzerinde sinırlayıcı yetkileri bulunmaktadır. Bu noktada temel hak ve özgürlüklerin güvence altına alınabilmesi için her zaman hukukun üstünlü̈̆̈̈ ilkesine ve hizmetin yürütülmesine ilişkin etik standartlara bağlı kalınması gerekmektedir. Bu çalışmada toplumsal hayatın düzenlenmesinde anahtar rol oynayan değerler sisteminin genelde kamu hizmetlerinin yürütülmesinde, özelde ise güvenlik hizmetlerinin yerine getirilmesinde kamu yararı ve kamuya hizmet bilinci ilkelerinin zarar görmemesi için çalışanlar tarafindan içselleştirilmesinin gerekliliği tartışılmıştır. Bu kapsamda çalışmada, ahlaki yönetim ikliminin să̆lanması ve çalışanların mesleki bağlllıklarının kuvvetlendirilmesi önem kazanmaktadır.

Anahtar Kelimeler: Değer, Ahlak, Kamu yararı, Kamu hizmeti, Profesyonel polislik 


\title{
Public Services And Professional Policing In the Framework of Social Values
}

\begin{abstract}
While people are members of societies, they are also the executors of professional activities, which are an indispensable part of social life. Deficiencies experienced in moral decision-making and moral behavior within the framework of personal values lie behind the crises that affect societies and states. In order to avoid these deficiencies, services must be fulfilled within a moral sense of governance. Ethical principles and values are at the point of making this management approach effective. Values and principles that guide social life and stimulate human behavior play an important role in the execution of professional activities as well. The values affect the lifestyles of humans both emotionally and behaviorally, and form the basis of ethical principles for professions. Public services are the activities that are fulfilled by the purpose of the public interest. In this context, people who perform public service also have to prioritize the common benefit for society. Due to this nature of public services, it is important to consider services as a moral activity. Ethical management should not only be restricted to preventing unlawful behavior. Ethical management should also aim to support ethical behavior. Security services, which are part of public administration, are a service sector that aims for the safety and peace of people, not outright defense or attack purposes. Security services have restrictive authority over the use of fundamental rights and freedoms. At this point, in order to guarantee fundamental rights and freedoms, it is always necessary to adhere to the rule of law and ethical standards regarding the execution of the service. In this study, the necessity of internalizing the system of values by the employees that plays a key role in the regulation of social life in the execution of public services in general, in the fulfillment of security services in particular, not to harm the public interest and public service consciousness. In this context, it is important to ensure the moral governance climate and to strengthen the professional commitment of employees.
\end{abstract}

Keywords: Value, Morality, Public interest, Public service, Professional policing 


\section{Giriş}

İnsanların düzen içerisinde bir arada yaşadıkları toplum hayatı, insan davranışlarında öncelikleri belirleyen ve davranışları yönlendiren değerler sisteminden oluşmaktadır. Değerler sistemi ilk çağlardan itibaren doğru ve yanlış davranışı belirlemede, iyi ve kötüyü ayırt etmede rol oynayan ilkelerin tartışılması sonucu ortaya çıkmıştır. Modern devletlerin değer yargılarının oluşumu ve doğru davranışın açıklanmasına ilişkin yaklaşımlar, düşünürlerin ahlak felsefesinde vurgu yaptıkları tanımlamalar üzerinden çeşitlenmektedir. Sokrates, Platon, Aristoteles, Aristippos, Epikuros, Diogenes, Spinoza, Jeremy Bentham, J. Stuart Mill, Kant, iyi ve kötünün insanlar için ne ifade ettiğini farklı açılardan ele alarak yaklaşımların gelişimine katkıda bulunmuşlardir.

İnsanlar toplumların birer ferdi olmakla beraber, toplumsal hayatın vazgeçilmez parçası olan mesleki faaliyetlerin de yürütücüsüdürler. Bu minvalde toplumsal hayata yön veren ve insan davranışarın harekete geçiren değerler, mesleki faaliyetlerin yürütülmesinde de önemli rol oynamaktadır. Bireylerin modern devletin hizmet anlayışı içerisinde kamu yönetimi sistemine dâhil olması, mesleki ilke ve değerleri de etkilemektedir. Bu etkileşim sonucunda kurumsal kültürler şekillenmektedir. Hülasa, kamu hizmetlerinin yürütülmesinde kamu yararı bilinciyle hareket etme konusunda oluşabilecek olası çelişkilerin ortadan kaldırılması için değerler önem kazanmaktadır. Kurumsal değerler, çağın gereksinimlerine uygun ilke ve değerleri kapsamakla birlikte çalışanların her türlü yeniliğe ve dönüşüme uyum sağlamalarını da amaçlamaktadır. Bu sayede günümüz ve gelecek nesiller arasında oluşabilecek muhtemel anlayış farklılıkları ortadan kalkacaktır. Bu vizyon, kolluk hizmetlerinin yürütülmesinde vatandaşların beklentileri doğrultusunda sürdürülebilir güvenlik anlayışının tesis edilmesi için oldukça önemlidir.

Demokratik toplumlarda profesyonel polislik anlayışı, bireylerin huzur ve güvenliğini sağlamakla birlikte temel hak ve özgürlüklerin güvence altına alınmasında önemli rol oynamaktadır. Bu nedenle güvenlik hizmetlerinin mesleki değerler ve yasal mevzuatlar çerçevesinde etkin ve verimli çalışması modern hukuk devletlerinin temel özellikleri arasında yer almaktadır. Kamu düzeni ve insan haklarının korunması noktasında oldukça işlevsel olan güvenlik hizmetlerinin kurumsal değerler ekseninde yürütülmesi kamu yararı 
bilincine hizmet etmektedir. Güvenlik hizmetlerine ilişkin meslek ahlak ilkeleri, kamu yararını gözeterek yasal kurallar çerçevesinde hareket etmeye zorlayan, aykırı davranışları engelleyen değerler bütünüdür. Bu değerler mesleklerin hak ettiği saygınlığı kazanmasına yardımcı olmaktadır.

Bu çalışmada toplumsal hayatın düzenlenmesinde etkili olan değer yargilarının genel olarak kamu hizmetleri ve özelde ise polislik hizmetlerinde kurumsal kültürün oluşmasındaki etkisi incelenmiştir. Çalışma dört bölümden oluşmaktadır. Birinci bölümde toplumsal hayatın düzenlenmesine ilişkin temel değerler, ikinci bölümde değerler sisteminin ve ahlak kurallarının gelişimine etki eden felsefi yaklaşımlar, üçüncü bölümde değerler sistemi ve kamu hizmeti ilişkisi, dördüncü bölümde ise güvenlik hizmetleri ve profesyonel polislik anlayışı ile değer yargıları arasındaki etkileşim incelenmiştir.

\section{Toplumsal Hayatın Düzenlenmesine İlişkin Temel Değerler}

Değerlerin somut örneklerle ifade edilmesi noktasında net bir tanımlama yapmak oldukça güçtür. Değerler, bireyin yaşantısındaki farklı davranış kalıplarına yüklenen anlamlardır (Pehlivan, 2002, s.13). Bir toplum içerisindeki insanların birbirleriyle olan ilişkilerini düzenleyen ve davranışlarını şekillendiren kurallar olarak tanımlanan normlardan (Pehlivan, 2002, s.15), daha geniş, kapsayıc ve genel bir anlamı ifade etmektedir. Değerleri basit bir şekilde duygusal ifadeler olarak açıklamak da yanlış olacaktır. Çünkü değerler, insanların yaşam biçimlerini hem duygusal hem de davranışsal olarak etkilemektedir (Apa ve Öktem, 2016, s.63). Değerler, etik ilkelerin temelini oluşturmaktadır. Etik ile ilgili ilkeler bir değerin uygulanması için gerekli olan davranış kalıplarının ifadesidir. Eylem ve davranışlara yön veren nesnel yasal metinlerin yanında, içsel değer ve tutumlar bulunmaktadır. Yasal metinler kamu yönetiminin fiziki bedenini oluştururken, değerler sistemi yönetimin ruhunu oluşturmaktadır (Apa ve Öktem, 2016, s.60). Değer kavramını genel olarak aşağıdaki şekliyle ifade etmek mümkündür (Rokeach, 1973, s.5, akt; Apa ve Öktem, 2016, s.63):

Değerler, belirli bir davranışı bireysel ve sosyal olarak zıt bir başka davranışa tercih edilmesine ilişkin kahıc inançlardır. Değerler sistemi, davranışların tercih edilmesine ilişkin görece önemliden önemsize stralanan bir doğrunun uzantısı şeklinde sürekli bir inanç düzenidir. 
Toplumsal hayatın düzenlenmesinde önemli bir rol üstlenmiş olan ahlak ise bireylerin sahip olduğu değerler çerçevesinde insanlar arası ilişkilere yön vermektedir. Türkçe'de kullandığımız ahlak kelimesi Arapça kökenli olup, insan davranışlarının doğru ve yanlış, iyi ve kötü olarak tanımlanmasında başvurulan ilkelerdir (Ülgen ve Mirze, 2004, s.35). Günümüze kadar geçen süreçte ahlak "bireyin toplumsal değerleri" olarak ifade edilmektedir (Pehlivan, 2002, s. 9-10). Ahlak, kültürel değerler ve ideallerle ilgili doğru ve yanlışları ve bunlara uygun olarak nasıl davranılması gerektiğini belirler. Başka bir ifade ile ahlak, nasıl davranılmasına ilişkin, yazılı olmayan standartları içermektedir. Ahlak ile bağlantılı ve ahlak kurallarının oluşumuna etki eden faktörleri; kültür, norm, aile, din, eğitim ve kitle iletişim araçları olarak ifade edebiliriz. Kültür, bir toplumun tarihsel süreç içerisinde ürettiği ve kuşaktan kuşağa aktarılan her türlü maddi ve manevi özelliklerin tümü olarak tanımlanmaktadır. Ahlaki gelişim temel dinamiklerini kültürden alır ve kültür, toplumun yaşayış ve düşünüş tarzını oluşturmaktadır. Norm, belirli bir grup için görgü kuralları, davranış bilgisi, töre gibi farklı şekillerde tanımlanmaktadır. Normlar değerlerin yansımasıdır ve toplumsal yaşamın önemli bir bölümünü kapsamaktadır. Aile, insan kişiliğinin oluşmasında ilk ve en önemli faktördür. Toplumun kültürel ve ahlaki değerlerini, nesilden nesile aktaran ve çocukları topluma hazırlayan en temel kurumdur. Din, insanın yaratılışı ve yazgısının kaynağı ile ilgili soruları cevaplandıran inanç sistemidir. Din, insanın iyi ya da kötü özelliklerinin harekete geçirilmesinde en etkili kurumdur. Dini inanç ahlak için psikolojik bir faktördür. Eğitim, bireyin davranışlarında kendi yaşantısı yoluyla ve kasıtlı olarak istenilen yönde değişim meydana getirme sürecidir. Kişinin yaşadığı toplum içinde yetenek, tutum ve diğer davranış biçimlerini geliştiren süreçlerin tümüdür. Eğitimin amacı, bireye belirli bilgi ve becerileri aktarıp, değer yargıları aşılayarak onda istenilen davranışları geliştirmektir. Bu amaç ahlaki değerleri de kapsamaktadır. Kitle iletişim araçları, küreselleşen dünyada insanların tutum ve davranışlarını, buna bağlı olarak etik ilke ve değerlerini etkileyen faktörlerden biridir. Radyo, televizyon, dergi ve kitaplar insanın sürekli olarak yeni bilgi edinmelerine neden olmakta ve bireylerin değer yargıları da bu görüşler doğrultusunda değişmektedir. (Kolçak, 2016, s. 55-61).

Etik, toplumsal düzeni sağlayan ahlak kuralları üzerinde çalışan ve söylem geliştiren felsefi bir disiplindir. Etik, yanlış davranışı doğrudan ayırmak için ahlak kavramını incelemektedir. Etiğin ilgi alanı, insan davranışlarıdır 
(Mengüşoğlu, 1965, s. 15). Etik, insan davranışlarına temel teşkil eden ahlaki ilkeler bütünüdür. Türk dil kurumunda etik, "töre bilimi", "bir meslek grubunun uymak zorunda olduğu davranışlar bütünü" olarak tanımlanmaktadır. Etik, insanlara neyin nasıl yapılması gerektiğini belirlemede liderlik eden ilkelerdir. Etik, aynı zamanda bir süreçtir. Bu süreçte karar alırken ve davranışta bulunurken, belirli değerlere bağlı kalınarak hareket edilir (Kamu Görevlileri Etik Kurulu, Etik Rehberi, 2017, s.11).

Ahlak, belirli bir topluma ve zamana ait davranış kurallarının yapısını incelerken, etik, genel olarak meslekler özelinde evrensel geçerliliği olan davranış kurallarını incelemektedir. Bu çerçevede ahlak toplumdan topluma ve zamana göre değişen yerel özellikler gösterirken, etik evrensel bir yapı arz etmektedir (Kolçak, 2016, s. 9). Etik, ahlaki davranışlar üretmez, ahlakla ilişkili sorunlar üzerinde ilkesel ve soyut tartışmalar yaparak eylem ve davranışlara doğru ve yanlış olması yönünden anlam kazandırır. Etik insanları ahlaklı yapmaz. İnsanların davranışlarının iyi ya da kötü olması, kendi iradeleri ile ilişkilidir. İnsanlar toplumsal yaşam içerisinde yaşayarak kendiliğinden ahlaki değer ve ilkeleri öğrenmektedir (Kolçak, 2016, s. 10). Etik ilke ve değerler ise ancak mesleki ilişkiler ve bir eğitim süreci sonucunda öğrenilmektedir. Ahlaki ilkelere uygun davranmamanın yaptırımı, kınama ve ayıplama şeklinde olurken, meslekler özelinde etik ilkelere aykırı hareket etmenin yaptırımı genellikle saygınlığın kaybedilmesi ve meslekten dışlanma şeklinde görülmektedir.

Hukuk, insanların birbirleri arasındaki ve devletle olan ilişkileri düzenleyip uyulması gereken kuralları belirlemektedir. Belirlenen kurallara uygun hareket edilmemesi durumunda ise hukuk, maddi yaptırımlar öngörmektedir. Ahlak ve etik kuralları da insan davranış ve eylemlerini sınırlandırmaktadır (Aktan, 2009, s.52). Ahlak ve etik kavramları biçim ve kapsamları açısından hukuk kuralları ile yakın bir ilişki göstermektedir. Adam öldürme, hırsızlık, rüşvet, dolandırıcılık gibi ahlaki ve etik olarak kötü sayılan davranışlar aynı zamanda hukuk kurallarının da suç sayarak yaptırıma bağladığı davranışlardır. Ancak hukuk kuralları, ahlak ve etik kurallarından yaptırım noktasında ayrışmaktadır. Ahlak kurallarının ihlali sonucu ortaya çıkacak olan yaptırım, ayıplama ve kınama şeklinde vicdani yönden olmaktadır. Etik kurallarının ihlali sonucunda ise yaptırımlar genel olarak meslekten dışlanma, saygınlığını ve güvenirliliğini kaybetme şeklinde görülmektedir. Hukuk ve 
etik kuralları yazılı hale getirilmiş olmasına karşın ahlak kuralları yazılı değildir.

\section{Değerler Sistemi ve Ahlak Kurallarının Gelişimine İlişkin Temel Felsefi Yaklaşımlar}

Ahlak kuralları ve değerlerin tarihsel gelişimine bakıldığında, insan yaşantısının anlamını açılama noktasında ilk çağ Yunan felsefi düşüncelerine kadar uzandığı görülmektedir (Kolçak, 2016, s.2). İnsanları felsefeye yönlendiren temel sebeplerden bir tanesi "Nasıl yaşamalıyız" ve "İnsanlar için hayat ne ifade eder" sorularına cevap verebilme çabası olmuştur (Warburton, 2016, s. 24-139). Bireylerin sosyal hayatlarında ve hayatlarını devam ettirmek için yürüttükleri meslek yaşantılarında nasıl davranmaları gerektiği arayışı, etik ilkelerin ortaya çıkmasına hizmet etmiştir.

Ahlak felsefesi olarak da tanımlanan etik, insan davranışların iyi veya kötü bir eylem olarak ifade edilmesinin teorik altyapısını oluşturmaktadır. Ahlak, kültürel değer kalıpları çerçevesinde doğru ve yanlış eylemleri belirleyerek, belirlenmiş olan bu ahlaki ilkelere uygun davranılmasının gerekliliğini ifade eder. Etik ise eylemlerin ahlaki kaynağını ve kapsamını inceler. Bu çerçevede etik bir davranış teorisidir. Başka bir ifade ile ahlak, eylemlerin pratiği ve uygulanmasına ilişkindir, etik ise pratik ve uygulamanın kuramsal, tanımlayıcı etkinliğidir. "Hırsızlı yapmak kötüdür" önermesi tanımlayıcı bir etik ifadesi iken, "hırsızlı yapma, cezalandırılırsı" önermesi kural koyucu bir ahlak ifadesidir (Akdemir, 2016, s.6). Etik ve ahlak kavramları birbiri içerisinde çözündügü için iki kavram arasında keskin çizgilerle bir ayrım yapmanın oldukça güç ve tartışmaya açk olduğunu söylemek mümkündür.

Sokrates, doğru davranışı mutlak gerçek ve bilgi edinme ile açıklamaktadır'1. Sokrates'e göre bir kişi, doğru olanı keşfederse, o kişi asla kötü bir davranış sergilemeyecektir. Bu çerçevede Sokrates'e göre kötü davranış, bilgi eksikliğinden kaynaklanmaktadır. Eğer insanlar doğru bir eğitim sürecinden geçirilirse iyi hayatın doğasını keşfedeceklerdir. Sokrates doğru davranışı açıklarken sıkça eleştirilen şu ifadeyi kullanmaktadır: "İnsanların yaşayabileceği sadece tek bir mutluluk vardır". Sokrates' in bu ifadesinin temelinde, iyiliğin

\footnotetext{
1 Sokrates'in düşüncelerini ifade ettiği yazılı bir eseri olmadığı için görüşleri genel itibari ile Platon'un Sokrates ile ilgili olarak yazdığı eserlerden alınmıştır.
} 
insanların duygu, düşünce ve eğilimlerine bağlı olmaması inancı bulunmaktadır (Stroll vd., 2017, s. 18). Ona göre iyilik ve mutluluk mutlak bir gerçektir ve kişilere bağlı olamaz. Sokrates bu yaklaşımı ile mutluluğun göreceli olduğunu savunan rölativizmden ayrılmaktadır. Sokrates'in insanların her durumda aynı davranışı göstereceği ifadesinin, psikolojik değerlendirmeler yönünden ciddi eksiklikleri bulunmaktadır. İnsanlar yalan söylemenin kötü bir eylem olduğunu bilirler; fakat yalan söylemeye yine de devam edebilirler. Sokrates bu durumda insanların yalan söyleme ile asıl ifade edilen gerçeğin ne olduğunu anlamadıklarını savunur (Stroll vd., 2017, s.19). Oysaki insanlar doğru davranışın ne olduğunu bildikleri halde yanlış davranışlarını sürdürmektedirler.

İnsanlar çoğu zaman nasıl davranacaklarını ya da karar vereceklerini bilemedikleri ikilemler ile karşı karşıya kalmaktadırlar. Sokrates bu durumda kalan insanların doğru eylem tarzının ne olduğunu bilmediklerini ifade etmektedir. Sokrates bu durumu, bir doktorun hastalar için ameliyat gerekli mi, değil mi ya da ilaç verilmeli mi yoksa verilmemeli mi noktasında yaşadığı ikilem ile anlatmaktadır. Eğitimsiz bir doktorun bu durumda çıkmazda kalacağı aşikârdır. Eğitimli bir doktor için ise böyle bir güçlük söz konusu olmayacaktır (Stroll vd., 2017, s.20). Sokrates birçok durumda söz konusu olan ahlaki karar verme ya da davranış gösterme çıkmazının doğru bilgi elde etmekle çözüleceğini belirtmektedir.

Platon'un ahlak anlayışında, insanların en yüksek iyiyi elde etme çabası bulunmaktadır. En yüksek iyi de insanları mutluluğa götürecektir. En yüksek iyi, bireylerin akli ve ahlaki olarak kendilerini geliştirmeleri ile gerçekleşmektedir. Platon, Sokrates' in bireysel ahlak yaklaşımından uzaklaşarak sosyal ahlak üzerinde durmaktadır (Özgener, 2018, s.36). Platon, tek kişinin mutluluğundan ziyade toplumun genel olarak nasıl mutlu olacağını araştırmaktadır. Platon toplumun gerçek anlamda mutluluğunun ancak devlet ile mümkün olabileceğini ifade etmektedir. Devletlerin asıl amacı, vatandaşların erdemli ve mutlu olmasının sağlanmasıdır. Platon'a göre devletlerin varlığı, bireylerin haklarını koruma ve adaleti sağlama amacına yöneliktir (Özgener, 2018, s.36).

Platon ayrıca insanların sade ve basit bir hayat sürmeleri gerekliliğine vurgu yapmaktadır. Ona göre aşırı zenginlik arzusu, insanların erdemlerini sinırlamaktadır. Erdemler ise mutluluğa giden tek yoldur. İnsanlar yaşamla- 
rını devam ettirecek ihtiyaçlarını karşılamakla yetinirse, daha iyi ve üstün karakterli olacaklardır. Platon, sosyal ahlak ve toplumun genel mutluluğuna vurgu yapmasından dolayı erdemler içinde adaleti en başa koymaktadır (Akarsu, 1998, s.112-113).

Aristoteles nasıl yaşamalıyız sorusuna mutluluk arayışı ile cevap vermiştir. Mutlu olmak için yaşamak ifadesinin birçok alt bileşeni bulunmaktadır. Peki, mutlu bir hayat neyi önermektedir? Hazza dayanan bir hayatı mı, başarı elde etmeyi mi, şöhret kazanmayı mı? Tatile ve festivallere gitmek, arkadaşlarla zaman geçirmek, sınavlarda yüksek not almak, kitap okumak, film izlemek gibi birçok eylemden bahsetmek mümkündür. Aristoteles tüm bu eylemlerin ve fazlasının mutlu yaşamın bir parçası olabileceğini fakat iyi bir yaşam için gerçek mutluluğun "eudaemonia" olarak ifade ettiği başarı ve gelişme ile sağlanacağını belirtmektedir (Warburton, 2016, s.25). Ona göre mutluluk, günlük yaşantımızdaki geçici mutluluk hislerimizden ziyade daha nesnel ve kapsamlıdır. En iyi yaşama, doğru karaktere sahip olarak ve aklın gücünü kullanarak ulaşmak mümkündür ve bunun en iyi yolu da iyi eğitimden geçmektedir. Ĕ̆itim, iyi davranış kalıplarını, iyi davranış kalıpları da erdem ve mutluluğu getirecektir. Kötü davranış kalıpları da kusur ve kötülüğe neden olacaktır. Aristoteles mutluluğa ulaşmak için yaşamdan alınan geçici hazlar yerine daha iyi bir insan olmaya ve doğru kararlar vermeye çalışılması gerektiğini savunmaktadır (Warburton, 2016, s.28).

Aristoteles' in mutluluğu elde etmek için nasıl yaşamalıyız sorusuna cevabı "Altın Orta" şeklinde ifade edilen bir formüldür (Stroll vd., 2017, s.25). Aristoteles mutlu olmak için yaşamayı, iyi beslenmek örneği ile açıklamaktadır. İyi beslenme konusunda; çok yeme ve az yeme arasında orta bir nokta vardır. Her insanın yaptığı işe ve fiziki yapısına göre değişen, alması gereken bir besin miktarı vardır ve insanlar kendileri için gerekli olan miktarı deneme yanılma yöntemiyle, açlık hislerini giderinceye kadar besin alırlar. Bu örneği, etik açıdan doğru yaşamaya aktaran Aristoteles, farklı insanlar için farklı doğru yaşam biçimlerinin olduğunu savunmaktadır. Bir insan için iyi olan, başkası için iyi olmayabilir ve insanlar kendileri için doğru olan mutluluk getirecek davranışı, akıllarını kullanarak ve deneme yanılma yöntemiyle keşfedebilirler. Mutluluk da; insanların nasıl davranacaklarını keşfettiklerinde, ölçülü olmak yani ortada olmakla sağlanabilir. Cesaret ve korkaklık, cömertlik 
ve savurganlık, alçak gönüllülük ve kibirli olmak gibi değerler arasında ortada olunmalıdır. Mutluluk iki aşırı uç arasında ortaya ulaşma çabası içerisinde gerçekleşmektedir (Stroll vd., 2017, s. 26).

Aristippos, yaşamın amacının en yüksek hazza erişmek olduğunu savunmaktadır ${ }^{2}$. Fakat Aristippos en yüksek haz ifadesi ile Sokrates ve Platon'dan ayrılmaktadır. Ona göre en yüksek haz anlık ve yoğun bir şekilde yaşanan mutluluktur. Aristippos'a göre geçmiş artık yoktur ve gelecek de belirsizdir. $\mathrm{Bu}$ sebeple mevcut zamann mutluluğu en geçerli olan mutluluktur (Stroll vd., 2017, s. 30). Kinetik haz olarak tanımlanan Aristippos'un mutluluk tanımı bir başka hedonizm savunucusu Epikuros tarafından farklı bir şekilde ele alınmaktadır.

Epikuros, Platon ve Aristoteles'in iyi hayatın hazla ilgisi olmadığı, akli ve ahlaki olarak insanların kendilerini geliştirmeleri ile iyi bir yaşamın gerçekleşeceği düşüncesinden Aristippos örneğinde olduğu gibi hedonist bir görüşle ayrılmaktadır. Epikuros, hazzı mutluluk için yegâne iyi olarak ifade etmektedir. Fakat Epikuros'un görüşü Aristippos'da olduğu gibi kinetik değil, statik bir hazzı ifade etmektedir. Başka bir ifade ile bütün yaşam boyunca sürekliliği olan hazzı savunmaktadır (Öztürk, 1998, s.2, akt; Özgener, 2018, s.38). Epikuros felsefesi, mutlu bir yaşam için sadece haz elde etme çabası içinde olunmaması gerektiğini, aynı zamanda acıdan kaçınmanın da mutlu bir hayat için vazgeçilmez olduğunu ifade eder. Eğer sonucunda acı getiren anlık haz verici eylemlerle meşgul olunursa bu hayat, kötü bir hayat olarak kabul edilmektedir (Stroll vd., 2017, s.30).

Hedonizmin hazcı yaklaşımının tam tersini savunan Diogenes, dünyaya ait şan, şöhret, zenginlik gibi her türlü hazzın terk edilmesi gerektiğini ifade etmektedir ${ }^{3}$. Çünkü mutluluğu bu tarz şeylere sahip olmaya dayandırırsak asla mutlu olamayız. Diogenes, dünyanın temelde kötü olduğuna inanmaktadır. Eğer insanlar mutlu olmak istiyorsa bunu kendi içlerinde aramalıdır (Öztürk, 1998, s.2). Diogenes'in bu görüşlerinde Yunan site devletlerinin y1kılmasına neden olan savaşların, savaşlar sonucunda yaşanan büyük kayıpların ve kurumların işlemez duruma gelmesinin etkili olduğunu savunan görüşler de bulunmaktadır. Bu görüşe göre insanlar söz konusu kaos ortamında kişisel kurtuluşa yönelmişlerdir.

\footnotetext{
${ }^{2}$ Yaşamın gerçek amacının en yüksek hazza ulaşmak olduğunu savunan görüş, hedonizm olarak da ifade edilmektedir.

${ }^{3}$ Diogenes'in ifade ettiği bu görüş çilecilik ya da Kınikçilik olarak da bilinmektedir.
} 
Spinoza, şan şöhret ve zenginliğin bir amaç olarak kabul edilerek hareket edildiğinde, insanların mutluluğu için bir engel teşkil edeceğini savunmaktadır. Ancak zenginlik ve diğer duygusal hazlar, mutluluk için bir araç olarak kabul edildiğinde iyi bir yaşam gerçekleşecektir. Spinoza'ya göre insanlar beşeri güçlerinin sınırlı olduğunu kavradıklarında, duygusal hazlarının kölesi olmaktan kurtulacak ve iyi bir hayat yaşayacaklardır. Zenginlik ve duygusal hazlar asli olarak değerli değillerdir (Stroll vd., 2017, s.103-105). Spinoza ayrıca iyi ve kötünün kişiye göre değişeceğini savunarak rölativist bir yaklaşım sergilemiştir.

Jeremy Bentham ve John Stuart Mill, mutluluğu, fayda ilkesi ile ilişkilendirerek ifade etmektedir. Acının yokluğu ve hazzın varlığını mümkün olduğunca çok sayıda insan için geçerli olduğunda kabul etmektedir. Bir eylemin getireceği mutluluk, topluma olan faydası ile ölçülmektedir. Bir davranışı, alternatif eylemlerle karşılaştırdığınızda toplum için en büyük mutluluğu getireceğini düşündüğünüz eylem, iyi ve faydalı olandır (Warburton, 2016, s. 188). Başka bir ifade ile bir eylem, en çok sayıda insana, en yüksek oranda mutluluk ortaya çıkardığı kadarıyla doğrudur (Stroll vd., 2017, s.118). Bentham ve Mill, davranışlarımızın doğruluğunu ve yanlışlığını olası sonuçlara göre değerlendirmektedir ${ }^{4}$. Yalan söylemek eğer bir mutluluk üretecekse, o şartlar altında doğru bir eylem olarak kabul edilmesi mümkündür (Warburton, 2016, s.188). Bu durum aşağıda incelenecek olan Kant'ın ahlak anlayışı ile çelişmektedir.

Bentham ve Mill, fayda ilkesini, bir eylemin doğru ya da yanlış olduğunu belirlemede ölçü olarak kullanmıştır. Eylemin sonuçlarına odaklanan bu yaklaşım için eylemlerin tüm sonuçları ortaya çıkana kadar bu yaklaşımı kullanmanın uygun olamayacağı sonucuna ulaşılmaktadır. Fakat faydacılar bu duruma çözüm olarak, sonuçların olasılık derecesi ile belirlenebileceğini ifade etmişlerdir. Faydacılığı savunanlar, eylemlerin ortaya çımasını sağlayan motive unsurlarını dikkate almadıkları yönünde de eleştirilmektedir (Stroll vd., 2017, s.121-123).

\footnotetext{
${ }^{4}$ Davranışların iyi ya da kötü olduğuna, olası sonuçlara bakılarak karar vermek teleolojik yaklaşım olarak ifade edilmektedir. Davranışlar için önemli olan, gerçekleştirilmesi halinde elde edilmesi beklenen fayda veya mutluluk miktarıdır. Yaklaşıma göre eylemleri iyi ya da kötü yapan sonuçlarıdır (Sökmen, 2016, s. 42).
} 
Kant' a göre insanlar duyguları ve eğilimlerini sınırlayarak, bir eylemi yapmak zorunda oldukları için yaptıklarında ahlaki davranış ortaya çıkmaktadır. Kant'ın ahlaki davranışı, insanların ödevleri ve yükümlülükleri ile ilgilidir $^{5}$. Ahlaki davranış, eylemleri gerçekleştiren insanların motive unsurlarına indirgenmemelidir (Stroll vd., 2017, s.126). Bunu bir örnekle açıklayalım. Biri size gelip, zor durumda olduğunu anlatıyor ve sizden yardım istiyor. Eğer sizden yardım isteyen kişinin bu durumuna üzülüp yardım edersiniz, bu davranışınız Kant'a göre ahlaki bir davranış olmayacaktır. Çünkü Kant'a göre ahlak ne yaptığımızla ilgili değildir. Ahlak eylemlerin neden yapıldığı ile ilişkilidir. Doğru davranış, nasıl hissettiğimizin yönlendirmesi ile gerçekleştirilemez. Doğru davranış, ödevimiz olduğu için o davranışı işaret eden akılla gerçekleştirilebilir. Bu çerçevede Kant, ahlaki eyleme duyguların karıştırılmaması gerektiğini savunmaktadır (Warburton, 2016, s.175-176). Kant, ödev ahlakında duygusal davranışların şansla ilişkili olduğunu ifade etmektedir. Bazı insanlar merhamet ve empati kurarak hareket ederken, bazıları ise zalim ve şefkatsiz olabilmektedir. Bu sebeple iyi davranışlar sergilemek, insanların akıllarını kullanarak gerçekleştirdikleri seçimler ile mümkün hale gelmektedir.

Kant hiçbir zaman yalan söylenmemesi gerektiğini savunmaktadır. Yalan söylemek ahlaki olarak yanlış bir davranıştır. Doğru söylemek ise bir ödevdir ve hepimiz için kesin bir koşuldur. Sonuçları ve koşulları ne olursa olsun yalan söylenmemesi iyi bir yaşam için gerekliliktir. Başkalarını veya kendimizi zor bir durumdan kurtarmak için söylenen beyaz yalanlar da Kant için yanlış bir davranıştır. Çünkü Kant'a göre yalan söylemenin hiçbir istisnası yoktur (Warburton, 2016, s.178).

John Rawls, faydacılık ve ödev ahlakını kullanarak, kurumların ahlaki açdan değerlendirilmesine yönelik bir yaklaşım benimsemiştir. Rawls, adalet teorisi olarak ifade edilen yaklaşımında, eylemlerin doğru ve tarafsız olarak gerçekleştirilmesini ve iyinin maksimize edilerek adaletli ve tarafsız dağıtılmasına vurgu yapmaktadır (Özgener, 2018, s.47). Rawls, yaklaşımında adil toplum ifadesini kullanmaktadır. Bu tanım ile farklılıkların ve eşitsizliklerin savunulabildiği ve farklılıkların hoş görüldüğü bir yönetimi ifade etmektedir. Ayrıca adaletin dağıtımı, telafi edilmesi, ceza ve ödül sistemi gibi yöntemlerle adaletin sağlanması üzerinde durmaktadır (Özgener, 2018, s.48).

\footnotetext{
${ }^{5}$ Kant'ın ödev ahlakı deontolojik yaklaşım olarak da ifade edilmektedir.
} 


\section{Toplumsal Değerler ve Kamu Hizmeti İlişkisi}

İnsan hayatının her döneminde tartışılmış olan ahlaki davranış kavramı, Sanayi Devrimi ve özellikle küreselleşme süreci sonucunda kamu hizmetlerinin yerine getirilmesinde ve vatandaşların beklentilerinin karşılanmasında önemli bir ölçü olarak karşımıza çıkmaktadır. Kamu hizmeti, kamu yararı amacı güderek, kamu kurumları veya kamu kurumlarının denetiminde faaliyet yürüten özel hukuk tüzel kişilerince yerine getirilen hizmetlerdir. Kamu hizmetini icra eden kişiler de toplum için ortak faydayı önceledikleri, denetim ve hesap verebilirlik ilkeleri çerçevesinde hareket ettikleri için her zaman daha dikkatli davranmak zorundadırlar. Kamu yönetimi anlayışı yirminci yüzyılın sonlarına doğru, hızlı bir değişim sürecine girmiştir. Bu süreç, teori ve pratiğe fiziki ve manevi olarak birçok yeni kavram ve kurum kazandırmış veya mevcut kurum ve kavramların yeniden yorumlanmasın zorunlu kılmıştır. Bu kapsamda hesap verebilirlik, tarafsızlık, şeffaflık, yönetişim ve etik gibi kavramlar daha çok tartışılır hale gelmiştir (Eryılmaz ve Biricikoğlu, 2011, s.20).

Geleneksel anlamda kamu kurumlarının temel rolü, sonuç odaklı ve hizmetin sağlanması ile sınırlı iken, günümüzde hizmetin nasıl sağlandığı, vatandaşların beklentilerine karşılık verilmesi ve sosyal sorumluluk çerçevesinde genişlemiştir (Özgener, 2018, s.1). Birey-birey, birey-toplum, birey-devlet ve toplum-devlet ilişkilerinin yerel sınırlardan çıkıp, küresel bir hal aldığı günümüz bilgi toplumlarında, insan odaklı hizmet anlayışına doğru bir adım atılmıştır. Bu çerçevede özellikle kamu hizmetlerinde insan hakları bilinci, eşitlik, özgürlük ve sorumluluk gibi kavramlar önemli bir yer tutmaktadır. Toplumları ve devletleri etkileyen krizlerin temelinde yukarıda ifade edilen değerler çerçevesinde yaşanan ahlaki karar alma ve ahlaki davranışlar göstermede yaşanan eksikler yatmaktadır. Bu eksiklikleri ortadan kaldırmak için özellikle yöneticilere, ahlaki bir yönetim iklimi (Özgener, 2018, s.2) içeresinde hizmetlerin yerine getirilmesinin sağlanması sorumluluğu düşmektedir. Bu yönetim anlayışını hâkim kılma noktasında da etik ilke ve değerler karşımıza çıkmaktadır.

Meslek ahlakı, insanların bireysel, toplumsal ve iş ilişkilerini iyi-kötü, doğru-yanlış gibi ahlaki önermeler üzerinden araştıran, düzensizliği ve kuralsızlığı önlemek için değerler sistemi öngören bir felsefe disiplinidir. Etik, 
ahlaki değerler çerçevesinde insan davranışlarını değerlendirmesinden dolayı ahlak felsefesi olarak da tanımlanmaktadır (Nuttal, 1997, s. 15). Etikkamu ilişkisi ise toplum ve ahlak arasındaki ilişkiler bütününden hareketle, kamu hizmetlerinin yerine getirilmesinde geçerli olan ilkeler ile ortaya çımaktadır. Kamu hizmetlerinde etik, hizmetlerin niteliği, evrensel ve herkes için geçerli olma noktalarında karşımıza çımaktadır 6 . Kamu hizmetlerinde etik ilkeler, toplumsal ahlak kurallarından etkilendiği için ahlak kuralları ile arasında farklılıklar olduğu kadar kesişmeler ve benzerlikler de bulunmak$\operatorname{tadır}^{7}$ (Önkal ve Sümer, 2016, s.43).

Kamu hizmetlerinin yerine getirilmesinde temel amaç, kamu yararıdır. Kamu yönetiminin varlık sebebi o ülkenin vatandaşları, kamu hizmetinin varlık sebebi ise vatandaşların refahının sağlanmasıdır. Bu çerçevede kamu görevlilerinin davranışlarına yön veren temel ilke kamuya hizmet bilincidir (Brereton ve Temple, 1999, s. 456). Etik ile kamu ilişkisi çerçevesinde, bireysel çıkardan farklı ve bireysel çıkarın üstünde bir kamu iyiliği ifadesi sıkça kullanılmaktadır. Bu ifade, kamusal faaliyetlerin hukuka uygunluğunun denetlenmesinde önem taşımaktadır (Önkal ve Sümer, 2016, s.44-45). Platon “Devlet" isimli kitabındaki, "hiçbir yönetici, yönetimde kendi faydasını önceleyemez. Yönetilen kişilerin yararın gözeterek hareket eder." ifadesi ile kamu yararı kavramının önemine vurgu yapmıştır (Platon, 2011, s.34). Aristoteles ise belirli bir topluluğun çkarı gözetilerek gerçekleştirilen yönetim anlayışının, toplumsal yaşamda sapmalara neden olacağını ifade etmiştir (Aristoteles, 2010, s.81). Günümüzde kamu yararının gözetilmesi noktasında, kamu hizmetlerinin icrasında sadece maddi ve fiziki şartların iyileştirilmesi yeterli olmayacaktır. Aynı zamanda kamu görevlilerinin doğru karar verebilmesi ve doğru davranışlar gösterebilmesi için etik ilke ve değerlerin yaygınlaştırılması da gerekmektedir.

Kamu yönetimi, vatandaşa karşı güven ve yükümlülük çerçevesinde faaliyetlerini yürütmektedir. Hizmetlerin niteliğinden dolayı yönetimin parçası

\footnotetext{
${ }^{6}$ Kamu görevlilerden hizmet esnasında beklenen davranış kalıpları, yasal metinler ile düzenlenmiştir ve kişisel istisnaları bulunmamaktadır. Hizmetlerin niteliği noktasında da dünyanın her yerinde kamu hizmetlerinin yerine getirilmesinde aynı değer ve ilkelerin geçerli olduğunu söylemek mümkündür. Bu çerçevede etik ilkeler "biz" öznesi ile hareket etmektedir ve evrensellik arayışı içerisindedir.

${ }^{7}$ Kamu görevlerinin ifasında çalışan personel aynı zamanda kurumsal yapının bir parçasıdır. Bu durum kamu kurumlarının bireysel etkilere de açık olduğunu göstermektedir. Bu çerçevede kamu hizmetlerinin kurumsal boyutlarının yanı sıra bireysel ahlaki değer ve ilkeler boyutunun da olduğunu söylemek mümkündür.
} 
olan hizmetlerin ahlaki bir faaliyet olması önem arz etmektedir (Lawton, 2005: 240, akt; Yıldırım, 2016, s. 80). Etik yönetim, sadece yasalara uygun olmayan davranışları önlemekle sınırlandırılmamalıdır. Etik yönetime aynı zamanda etik davranışları desteklemeyi amaçlayan daha geniş bir pencereden bakılmalıdır (Maesschalck, 2004, s. 26). Bu bağlamda yönetimler tarafından, çalışanların eğitimine önem verilmeli, yöneticiler personeline doğru davranışı vurgulayan bir rol model olmalı ve etik sorunların rahatlıkla ifade edildiği bir çalışma ortamı oluşturulmalıdır. Bu sayede kamu hizmetlerini yürüten personel üzerinde, kişisel hesap verebilirlik formu ya da içsel bir kontrol geliştirmek mümkün olacaktır (Luk, 2012: 362, akt; Yıldırım, 2016, s. 80).

Bireylerin sahip olduğu değerler ve vicdanları, kamu görevlilerinin karşılaştıkları olaylarda gösterecekleri davranışları da etkilemektedir. Kurumsal kurallarla bireylerin sahip olduğu değerleri değiştirmek oldukça güçtür. Çünkü değerler bireylerin kamu hizmetine girmesinden çok önce oluşmuş ve şekillenmiştir (Apa ve Öktem, 2016, s. 64). Bireylerin değerlerinin oluşum sürecine aile, arkadaşları ile sosyalleşme, eğitim ve kültürel kalıplar etki etmektedir. Bu sebeple bireylerin kamu hizmetlerine girmeden önceki eğitimi ve yetiştirilme şartları oldukça önemlidir. Kamu değerlerini sistematik olarak düzenlemek konunun genişliği nedeniyle oldukça zordur. Bu yüzden değerlere yönelik çeşitli sınıflandırmalar yapılmıştır. Kamu hizmetlerinde çalışan bireylere ilişkin temel değerlere örnek vermek gerekirse; dürüstlük, tarafsızlık, yasal metinlere bağllık, halka hizmet bilinci, profesyonellik, hesap verebilirlik ve sosyal sorumluluk gibi örnekler sıralamak mümkün olacaktır.

Kamu kurumlarındaki bürokratik yapıyı açıklayan Weberyen bürokrasi, bireyleri birer makine gibi görmüş, temelde verimlilik ve etkinlik çerçevesinde kurumların işleyişini ifade etmiştir. Weber bürokrasiyi, hiyerarşi, biçimsellik, iş bölümü, uzmanlaşma ve emir ile açıklamıştır. Bu yapı, etik ilkelere ilişkin bir temel oluşturmak için yetersiz kalmaktadır. Çünkü kamu hizmetlerindeki etik sorunlar, sadece yasal metinler ile sınırlı kalmamakta, kültürel ve değerlere ilişkin de analiz gerektirmektedir (Ömürgönülşen ve Öktem, 2009, s. 143). Günümüzde sıkça kullanılan yönetişim kavramı çerçevesinde yeniden şekillenen yeni kamu hizmeti anlayışında ideal bir etik ilkeler bütününden bahsetmek mümkündür.

Yeni kamu yönetimi anlayışı ile birlikte kamu hizmetlerinde, özel hukuk tüzel kişilerinde geçmişten bu yana daha çok kullanılan; etkinlik, verimlilik, 
tutumluluk ve kalite gibi kavramlar, ön plana çıkmıştır. Bu anlayış çerçevesinde yapılan yeni reformlar, kamu hizmetlerinde hesap verebilirlik anlayışı ve pratiğinde önemli değişikler yapmıştır (Eryılmaz ve Biricikoğlu, 2011, s. 20). 1980 'li yıllardan itibaren yönetişim kavramının yaygınlaşması ile birlikte yukarıda ifade edildiği üzere, kamu hizmetlerinde işletme bakış açısı etkili olmaya başlamıştır (Yıldırım, 2016, s. 82). Bu çerçevede etik açıdan duyarlı kamu görevlilerinin görev tanımlarındaki hizmetleri layıkıyla yerine getirmelerinin yanında, vatandaşların beklenti, istek ve ihtiyaçları doğrultusunda da hareket etmelerinin gerekliliği konuşulmaya başlamıştır. Bu süreçte, içsel ve toplumsal bir sorumluluk ile kamu hizmetlerinin vatandaşların beklentilerine uyum sağlaması için geliştirilmesi temel beklenti haline gelmiştir. Böylece etkileşim, paylaşılan değerler, işbirlikçi karar alma süreçleri, katılımcı vatandaşlık ilkeleri bu süreçte sıkça kullanılan kavramlar olarak karşımıza çıkmaktadır (Yıldırım, 2016, s. 84-85).

\section{Kamu Yönetiminde Etik Dışı Davranışlar, Nedenleri ve Yöneticilerin Sorumluluklarn}

Kamu hizmetlerinde görülen etik dışı davranışların temelinde, fikirsel yakınlık, yeterli mesleki bilgiye sahip olmama, önyargılar, bencillik, çıkar ve fayda sağlama gibi bireysel sebepler bulunmakla birlikte kurumsal olarak çalışanların iş arkadaşlarına ve çalışma ortamına uyum sağlayamaması bulunmaktadır (Örselli, 2010, s. 72). Kamu hizmetlerinde genel olarak görülen etik dışı davranışlar ve nedenlerini aşağıdaki gibi sıralayabiliriz:

Kamu hizmetlerinde görülen etik dışı davranışlar;

- Yetkinin Kötüye Kullanılması, İhmal, Savsaklama

- Yolsuzluk / Usulsüzlük

- Psikolojik Yıldırma (Mobbing), Hakaret, Dedikodu

- Bilgi Edinme Hakkının İhlali

- Kayırmacilık / Ayrımcilık

- Kamu Malları ve Kaynaklarının Hizmet Gerekleri Dışında Kullanılması

- Rüşvet

- Zimmet

Kamu hizmetlerinde etik dışı davranışların olası nedenleri;

- Yetersiz Eğitim 
- Bilgisizlik

- Disiplinsiz Davranışlar

- Denetim Eksikliği

- Ruhsal Bozukluklar

- Kişisel Düşünce ve Önyargılar

- Aşırı Hirs

Etik yönetim iklimi, etik-kamu yönetimi ilişkisi bölümünde ifade edildiği üzere etik dışı davranışlara neden olabilecek faktörlerin ortadan kaldırılması için yöneticilere sorumluluklar getirmektedir. Etik yönetim, etik dışı davranışları önlemenin yanı sıra, etik davranışları desteklemeyi de amaçlamaktadır. Bu bağlamda yönetimler tarafından, çalışanların eğitimine önem verilmeli, yöneticiler personeline doğru davranışı vurgulayan bir rol model olmalı ve etik sorunların rahatlıkla ifade edildiği bir çalışma ortamı oluşturulmalıdır. Etik ilke ve değerlerin pekiştirilmesi için yöneticilerden beklenen davranışları ise aşağıdaki şekliyle sıralayabiliriz (Kavsıracı, 2018, s. 1874):

- Yöneticiler mahiyetinde çalışan personele rol model oluşturdukları için günlük işlerini yerine getirirken etik ilke ve değerleri sürekli olarak telaffuz etmeli ve bu ilkeler çerçevesinde davranışlarını düzenlemelidirler.

- Kurumun amaçları ve değerleri tüm personele anlatılmalıdır.

- Hizmetler açıkça tanımlanmalıdır ve herhangi bir ihlal durumunda uygulanacak yaptırımlar belirlenmelidir.

- Çalışan personelin faaliyetleri ile ilgili olarak sorumluluk alınmalıdır.

- Mevcut iş ile ilgili olarak personel seçerken, liyakat, davranış ve gelişim potansiyelleri dikkate almalıdır. Tüm personele adil, tarafsız ve eşit davranılmalıdır.

- Karar alma süreçlerinde ve davranışlarında dürüst, güvenilir ve adil olunmalıdır.

- Görev ile ilgili olarak etkililik ve verimlilik konularında taviz verilmemelidir.

- Karar alma süreçlerinde personelin görüşlerine değer verilmelidir.

Türkiye'de Kamu Yönetimi-Etik İlişkisi Çerçevesinde Yürütülen Çalışmalar

Günümüzde tüm dünyada gerek özel hukuk gerekse de kamu hukuku tüzel kişilerinin yürüttüğü faaliyetlerde, etik ilke ve değerlere verilen önem gide- 
rek artmaktadır. Türkiye'de de bu eğilim çerçevesinde etik davranış kültürünün yerleşmesi için çalışmalar yürütülmektedir. Türkiye'de kamu yönetiminde etik davranış kültürünün yerleşmesi için çalışmalar yapmak üzere 2004 yılında 5176 sayılı Kanun ile Kamu Görevlileri Etik Kurulu kurulmuştur. Etik Kurulu, kamu görevlerine ilişkin etik ilkeleri belirleme, etik davranış ihlallerine ilişkin denetim gerçekleştirme ve etik davranışların içselleştirilmesi için çalışmalar yürütme görevlerini üstlenmiştir. Etik Kurul, kamu hizmetlerini yürüten bireylerin nasıl davranmaları gerektiği noktasında aşağıdaki temel ilkeleri benimsemiştir (Etik Kurulu, 2015, s. 4).

- Kamu görevlilerinin hizmet sunduğu bireylere karşı yasal mevzuat çerçevesinde adaletli ve tarafsız davranması,

- Kamu hizmeti sunumunda; etkili, verimli ve kaliteli hizmetin gözetilmesi,

- Hizmet sunumunda karşılaşılan şikâyetlerin dikkate alınması ve değerlendirilmesi,

- Hizmetin sunulduğu çevreye karşı dürüst ve güvenilir olunması,

- Kamu görevlilerinin davranışlarında şeffaf olması ve hesap verebilirlik ilkesi çerçevesinde hareket etmesi

Etik Kurul'un, kamu görevlilerinin mesleki davranış ve ilkelerinin belirlenmesi için gerçekleştirdiği çalışmalar sonucunda, 2010 tarihinde "Кamu Görevlilerinin Uyacakları Mesleki Davranış İlkeleri Hakkında Yönetmelik" yürürlüğe girmiştir. 22 Şubat 2010 tarihli "Saydamlığın Arttırlması ve Yolsuzlukla Mücadelenin Güçlendirilmesi Stratejisi" kapsaminda kurul, her meslek grubu için etik ilkelerin belirlenmesi çalışmalarına başlamıştır. Etik Kurulu 5176 sayılı Kanunun 3. maddesi çerçevesinde, etik dışı davranışlara ilişkin gelen şikâyetleri de incelemektedir. Bu kapsamda 2005-2014 yılları arasında toplam 1821 adet başvuruyu incelemiştir. 2016 ve 2017 yıllarında da toplam 271 başvuru üzerinde inceleme yapılmıştır (Etik Kurul, 2015, s. 14, 2017, s. 12). Etik Kurul'un şikâyetler üzerine gerçekleştirdiği inceleme konuları şunlardır (Etik Kurul, 2017, s. 12):

- Genel Etik Davranış İlkelerine Aykırılık

- Görev ve Yetkilerin Menfaat Sağlamak Amaciyla Kullanılması

- Yolsuzluk/Usulsüzlük

- Çıkar Çatışması İddiaları

- Psikolojik Yildırma (Mobbing)

- Bilgi Edinme Hakkının İhlali 
- Kayırmacilık / Ayrımcilık

- Kamu Malları ve Kaynaklarının Hizmet Gerekleri Dışında Kullanilmasi

Etik Kurul; kamu yönetiminde etik davranış kültürünün yerleşmesi ve geliştirilmesi için projeler yürütmekte, etik bilincin gelişmesi amacıyla etik eğitimleri vermekte, araştırma, yayın, anket, toplantılar, sempozyumlar ve kamu spotları gibi faaliyetler de gerçekleştirilmektedir. Bu kapsamda kurul tarafından "Yolsuzluğun Önlenmesi ve Etiğin Teşviki (2015-2017)", "Yerel Yönetimlerde Etik Farkındalık (2016)" projeleri yürütülmüştür. Bu projelerde ulaşılmak istenen temel hedefler şunlardır (Etik Kurul, 2016, s. 15):

- Kamu Görevlileri Etik Kurulu'nun işleyişini ve hizmet sunumunu geliştirmek,

- Kamu ve özel sektör için etik ilke ve değerlerin önemini vurgulamak ve etik ile ilgili sorunlu konuları analiz etmek,

- Kamu sektörü, özel sektör ve STK'ların etik farkındalık düzeylerini değerlendirmek, yolsuzlukla mücadeleyi ve etik farkındalığı artırıc faaliyetler yürütmek,

- İş etiği kapsamında sendikalar, birlikler, meslek kuruluşları için etik ilkelerin geliştirilmesini desteklemek,

- Etik ilkeler, şikâyet mekanizmaları ve yaptırımlar konularında yayın, kitapçık, afiş ve broşürlerle toplumsal farkındalığı artırıcı çalışmalar yapmak.

\section{Bir Meslek Olarak Güvenlik Hizmetleri ve Profesyonel Polislik}

Meslek ifadesi genel olarak, insanların geçimlerini sağlamak için profesyonel olarak yaptıkları iş şeklinde tanımlanmaktadır. Bir işin profesyonel olarak tanımlanması için, o işin icrasına yönelik belirli bir teknik ve kuralların olması gerekmektedir (Sökmen, 2016, s. 35). Bir işi profesyonel olarak icra eden bireyler de işe ait teknik ve kuralları belirli bir eğitim sürecinden geçerek öğrenmektedir. Meslekler aynı zamanda toplumsal hayatın bir yansımasıdır ve işlevsel olarak toplumun devamı için gereklidir. İnsanların geçimi ve sosyal hayatları için vazgeçilmez bir yapı arz eden meslek kurumlarının önceden düzenlenmiş ilke ve kurallar çerçevesinde yürütülmesi toplumların geleceğ $i$ için de önemli bir unsur olarak karşımıza çıkmaktadır. Meslek etiği ilkeleri- 
nin çalışanlar arasında benimsenmesi için mesleki bağlllık ifadesi önem kazanmaktadır. Mesleki bağlılık, insanların yürüttüğü hizmeti içselleştirmesini ve mesleki faaliyetleri sürdürme isteğini tanımlamaktadır. Çalışanlar arasında mesleki bağlılık düzeyleri farklı seviyelerde olmaktadır. Mesleki bağlılık temel olarak üç seviyede gerçekleşmektedir. Bunlar (Kutlu, 2011, s. 87-88):

- Mesleki değer yargıların benimseme: Mesleğe ilişkin oluşturulan değer yargıları çalışanlar tarafından içselleştirilir. Bu noktada bireyler mesleki memnuniyeti gerçekleştiremeden toplumsal yaşantılarından haz alamazlar.

- Mesleki kariyer planlaması: Çalışanlar kendilerini yetiştirerek, meslekleri ile ilgili olarak yatırımlar yaparlar. Başka bir ifade ile mesleklerinde yükselebilmek için uzun vadeli planlar oluştururlar.

- Meslek öneminin artması: Çalışanların iş ve iş dışı faaliyetleri arasında tercih yapmaları noktasında mesleklerinin önem derecesi artmaktadır.

Meslek etiğinin temel amacı, meslek içerisinde ve toplumla olan ilişkilerde disiplin ruhunu geliştirerek, sunulan hizmetin etkinliğini ve kalitesini yükseltmektir. Meslek etiğini, icra edilen işin türüne göre tıp etiği, ticaret etiği, eğitim etiği, basın etiği ve polis etiği gibi farklı başlıklar altında incelemek gerekmektedir. Çünkü mesleğe özgü kurallar ve sunulan hizmetin niteliği, dikkat edilmesi gereken farklı kuralları ortaya çıkarmaktadır. Her ne kadar mesleklerin icra ettiği hizmetler farklı olsa da çalışma hayatında toplumların değer yargıları ile örtüşen temel ilkeler bulunmaktadır.

Bir meslek olarak güvenlik hizmetleri, günümüzde vatandaşların maksimum özgürlük-güvenlik beklentileri karşısında dengenin korunması için önemli bir işleve sahiptir. Güvenlik anlayışının statik bir yapıya sahip olmaması, güvenlik hizmet ve anlayışını, küreselleşmenin etkisine açk hale getirmektedir. Bu sebeple değişen yaşam şartları, sunulan güvenlik hizmetini de etkilemektedir. Modern yönetim teorisinin bir çıktısı olan yönetişim kavramının gelişmesi ile birlikte, güvenlik hizmeti de diğer kamu hizmetlerinin yaşamış olduğu niteliksel dönüşüme uyum sağlamıştır. Modern yönetim teorisi altında yer alan durumsallık yaklaşımı, yönetimleri dış çevre şartlarından etkilenmesi noktasında mekanik ve organik örgütler olarak sınıflandırmaktadır. Dış çevre şartlarının hızla değiştiği günümüz toplumlarında başarılı bir yönetim için hizmet sunulan vatandaşların beklentilerinin değerlendirilmesi anlayışı, organik yönetimleri temel almaktadır. Mekanik örgütleri ise dış çevre koşullarının dikkate alınmadığı klasik yönetim teorisinin işaret ettiği 
yönetimler olarak kabul edilmektedir (Tekiner ve İrdem, 2017, s. 60). Günümüz organik yönetimlerinin dâhil olduğu süreçte, kamu hizmetlerinde, vatandaşların beklenti, istek ve ihtiyaçları doğrultusunda hareket etmenin gerekliliği yönünde gelişmeler görülmektedir. Bu eğilim, ahlaki davranışın, insanların ödev ve yükümlülükleri ile açıklandığı, Kant'ın, "insanlar, duyguları ve eğilimlerini sinırlayarak, bir eylemi yapmak zorunda oldukları için yapmalılar" önermesi ile ifade edilen ödev ahlakı ile örtüşmektedir.

Güvenlik hizmeti, yasal şartlar gerçekleştiğinde temel hak ve özgürlüklere müdahale edebilen bir içeriğge sahip olmasına karşın, hizmetin niteliği değerlendirildiğinde eğitim, sağlık vb. diğer kamu hizmetlerinden hiçbir farkı bulunmamaktadır. Ayn zamanda güvenlik hizmeti, adli ve toplumsal olayları analiz edebilme, öncesi ve sonrasıyla bir bütün olarak olayları gözlemleyebilme fonksiyonlarını da içermektedir. Bu kapsamda güvenlik hizmetinin sosyal boyutu karşımıza çıkmaktadır. Bu çerçevede güvenlik hizmetini salt savunma veya saldırı amaçlı tanımlamak doğru değildir. Güvenlik hizmeti, yurttaşın güvenliği ve huzurunun amaçlandığı bir hizmet sektörüdür.

Günümüz hukuk devletlerinde kamu düzeninin sağlanması ve temel hak ve özgürlüklerin koruma altına alınması, toplumsal hayatın temelini oluşturmaktadır. Devletler, kamu düzeninin sağlanması kapsamında kurumsallaşmış ve profesyonel olarak görev yapan kolluk görevlileri aracılığ 1 ile güvenlik hizmetlerini yürütmektedir. Kolluk hizmetleri, genel ve özel kolluk görevlileri aracılığı ile icra edilmektedir. Kolluk hizmetlerinin temel unsurunu, kamu düzeni ve huzurunu tehdit eden veya etmesi muhtemel eylem ve davranışlar ile bu tür eylemlere karşı alınacak önlemler ve uygulanacak yaptırımlar oluşturmaktadır. Güvenlik hizmetlerine ilişkin çalışmalar değerlendirildiğinde ise genel olarak suç öncesi ve suç sonrası olmak üzere ikili bir ayrımın yapıldığı görülmektedir. Suç işlenmeden önce gerçekleştirilen güvenlik hizmetleri, önleyici ya da proaktif, suç sonrası yürütülen hizmetler ise adli güvenlik hizmeti olarak tanımlanmaktadır.

Güvenlik hizmetleri, içerisinde özgürlük kavramını da barındırmaktadır. Güvenliğin sağlanması beraberinde özgürlüğü de getirecektir. Başka bir ifade ile özgürlügüun olmadığ 1 bir yerde güvenlikten bahsetmek mümkün olmayacaktır. Özgürlük ve güvenlik birbiri ile karşıt anlamlar değil birbirlerini tamamlayan ifadelerdir. Bu sebeple özgürlük ve güvenlik ilişkisinin bütünlüğü için güvenlik hizmeti sunan personel ile halk arasındaki ilişkilerin hu- 
kuk kuralları içerisinde kalınarak yürütülmesi önem arz etmektedir. Güvenlik tedbirlerini haklı kılan unsur, hedeflenen amaçlar noktasında kullanılan araçların amaca uygun olmasıdır. Bireylerin özgürlükleri için güvenlik ön şart olduğu düşünüldüğünde, güvenlik uygulamalarının toplumun özgürlügü çerçevesinde getirdiği yükün kabul edilebilir olması gerekmektedir (Zedner, 2015, s. 161). Hedeflenen güvenlik ortamı için başvurulan araçlarda aşırıya kaçılmamalı ve hak ihlallerine göz yumulmamalıdır.

Küreselleşmenin etkisi ile birlikte son yıllarda, güvenlik hizmetlerinin sunumunda, görev tanımlarındaki hizmeti layıkıyla yerine getirmenin yanında, vatandaşların beklenti, istek ve ihtiyaçları doğrultusunda da hareket etmenin gerekliliği vurgulanmaktadır. Bu süreçte güvenlik hizmetlerinin, vatandaşların beklentilerine uyum sağlaması için geliştirilmesi temel beklenti haline gelmiştir. Böylece vatandaşlarla iletişim, işbirliği, şeffaflık, hesap verebilirlik ve katılımcı vatandaşlık ilkeleri bu süreçte sıkça kullanılan kavramlar olarak karşımıza çıkmaktadır.

Vatandaşa karşı sorumluluk ve hesap verebilirlik ilkeleri, hizmet sunumunda orantılı güç kullanma yetkisinin şeffaflı̆̆ını korumaktadır. Güvenlik hizmeti, hiyerarşi, disiplin, hizmet ilkelerine itaat ve emir-komuta zincirinin hâkim olduğu bir piramit yapıdan teşkil etmektedir. Bu çerçevede güvenlik hizmeti sunumunda, piramit yapının üzerinde bulunan yöneticilerin, kurum içi ilişkilerde ve hizmet sunumunun diğer tarafı olan vatandaşlara karşı tarafsız ve kurum hedeflerini önceleyerek hareket etmesi gerekmektedir. Kamu hizmetinin teknik ustası olarak kabul edilebilecek yöneticilerin, kurumlarında etik davranış ilkelerinin benimsenmesi açısından anahtar rol oynadığını söylemek mümkündür. Çünkü İnsan hak ve özgürlüklerinin korunması için önemli bir işlevi olan güvenlik hizmetinin doğru sunumu noktasında, yasal standartlara uymayan davranışların önlenmesinin yanı sıra etik davranış ilkelerinin benimsenmesi için doğru davranışı vurgulayan bir çalışma ikliminin oluşturulması da gerekmektedir.

Güvenlik hizmeti sunumunda kamu kaynaklarının kullanımı, etik ilkeler çerçevesinde başvurulan diğer önemli bir hizmet ilkesi olarak karşımıza çımaktadır. Kamu hizmetlerinde sarf malzemelerin yanı sıra en önemli kamu kaynağı insan kaynağıdır. Personelin yeteneği ve liyakati göz önünde bulundurularak, işe göre personel seçimini gözetmek, insan kaynağından maksimum verim elde etme noktasında en önemli faktördür. Polis yöneticilerine bu durumda da önemli görevler düşmektedir. Personelin yetenek ve çalı̧̧ma 
eğilimine hâkim olmalılar ve çalışanlarını, potansiyellerini ortaya çıkarabilecekleri işlere tayin etmelidirler.

Güvenlik hizmetini sunan kurumların bünyesinde meslek etiği ilkelerini işlevsel kılmak için uygulamalı ve teorik içeriği olan bir etik eğitim sürecinin işletilmesi de etik ilkelerin alışkanlık haline getirilmesine hizmet etmektedir. Teorik etik eğitimi ile hangi davranış kalıplarının mesleğe uygun, hangilerinin uygun olmadığını öğretmek mümkündür. Ancak özellikle yeni personelin etik değerlere saygı duyması ve etik davranış ilkelerini alışkanlık haline getirmesinde, yöneticilerin davranış ve tutumları önem kazanmaktadır. $\mathrm{Bu}$ durumda yöneticinin etik değerlere sahip olması ve bunu davranışlarında göstermesi gerekmektedir.

Yukarıda ifade edildiği üzere güvenlik hizmeti sunumunda yöneticilerin rol model olması, etik davranışları kuvvetlendirmek için sosyal öğrenme sürecine katkı sağlamaktadır. Ancak etik ilkelere uygun yönetsel kararlar almak, olası etik çelişkileri çözmek ve etik değerlerin güvenlik hizmetini icra eden diğer çalışanlar tarafından benimsenmesi için yönetim sürecini etik ilkeler ile yürütmek gerekmektedir.

Kolluk görevlilerinin temel hak ve özgürlüklerin kullanılması üzerinde sınırlayıcı yetkileri bulunmaktadır. Hatta yasal şartlar oluştuğunda istisnai hallerde öldürücü güç dahi kullanabilmektedirler. Bu yetkilerin kullanılmasının ne zaman ve ne şekilde gerçekleşeceğine dair karar verilmesi konusunda kolluk görevlileri takdir yetkisine sahiptir (Özyıldız, 2017, s. 47). Bu noktada temel hak ve özgürlüklerin güvence altına alınabilmesi için her zaman hukukun üstünlügü ilkesine ve hizmetin yürütülmesine ilişkin etik standartlara bağlı kalınması gerekmektedir.

\section{Sonuç}

Değerler, insanların yaşam biçimlerini hem duygusal hem de davranışsal olarak etkilemektedir. Değerler aynı zamanda etik ilkelerin temelini oluşturmaktadır. Etik ile ilgili ilkeler bir değerin uygulanması için gerekli olan davranış kalıplarının ifadesidir. Eylem ve davranışlara yön veren yasal metinlerin yanında, içsel değer ve tutumlar bulunmaktadır. Yasal metinler kamu yönetiminin fiziki bedenini oluştururken, değerler sistemi yönetimin ve davranışların ruhunu oluşturmaktadır. Bireylerin sosyal hayatlarında ve hayatla- 
rını devam ettirmek için yürüttükleri meslek yaşantılarında nasıl davranmaları gerektiği arayışı, değerlerin ve etik ilkelerin ortaya çıkmasına hizmet etmiştir.

İnsanlar çoğu zaman nasıl davranacaklarını ya da karar vereceklerini bilemedikleri ikilemler ile karşı karşıya kalmaktadırlar. Bu noktada Kant'ın ödev ahlakı karşımıza çıkmaktadır. Kant’a göre insanlar duyguları ve eğilimlerini sınırlayarak, bir eylemi yapmak zorunda oldukları için yaptıklarında ahlaki davranış ortaya çıkmaktadır. Kant'ın ahlaki davranışı, insanların ödevleri ve yükümlülükleri ile ilgilidir. Geleneksel anlamda kamu kurumlarının temel rolü, sonuç odaklı ve hizmetin sağlanması ile sınırlı iken, günümüzde hizmetin nasıl sağlandığı, vatandaşların beklentilerine karşılık verilmesi ve sosyal sorumluluk çerçevesinde genişlemiştir.

Kamu hizmetlerinin yerine getirilmesinde temel amaç, kamu yararıdır. Kamu yönetiminin varlık sebebi o ülkenin vatandaşları, kamu hizmetinin varlık sebebi ise vatandaşların refahının sağlanmasıdır. Bu çerçevede kamu görevlilerinin davranışlarına yön veren temel ilke kamuya hizmet bilincidir. Etik ile kamu ilişkisi çerçevesinde, bireysel çıkardan farklı ve bireysel çıkarın üstünde bir kamu iyiliği ifadesi sıkça kullanılmaktadır. Bu ifade, kamusal faaliyetlerin hukuka uygunluğunun denetlenmesinde önem taşımaktadır. Bireylerin sahip olduğu değerler ve vicdanları, kamu görevlilerinin karşılaştıkları olaylarda gösterecekleri davranışları da etkilemektedir. Kamu hizmetlerinde çalışan bireylere ilişkin temel değerlere örnek vermek gerekirse; dürüstlük, tarafsızlık, yasal metinlere bağlılık, halka hizmet bilinci, profesyonellik, hesap verebilirlik ve sosyal sorumluluk gibi örnekler karşımıza çıkmaktadır. Bu ilkelerle birlikte günümüzün yönetim anlayışında etkileşim, paylaşılan değerler, işbirlikçi karar alma süreçleri, katılımcı vatandaşlık ilkeleri sıkça kullanılmaktadır. Mesleklere ilişkin etik ilkelerinin çalışanlar arasında benimsenmesi için mesleki bağlılık ifadesi önem kazanmaktadır. Mesleki bağlılık, insanların yürüttüğü hizmeti içselleştirmesini ve mesleki faaliyetleri sürdürme isteğini tanımlamaktadır.

Güvenlik hizmeti, yasal şartlar gerçekleştiğinde temel hak ve özgürlüklere müdahale edebilen bir içeriğe sahip olmasına karşın, hizmetin niteliği değerlendirildiğinde eğitim, sağlı vb. diğer kamu hizmetlerinden hiçbir farkı bulunmamaktadır. Güvenlik hizmetleri, içerisinde özgürlük kavramını da barındırmaktadır. Güvenliğin sağlanması beraberinde özgürlüğü de getirecektir. Başka bir ifade ile özgürlüğün olmadığı bir yerde güvenlikten bahsetmek 
mümkün olmayacaktır. Özgürlük ve güvenlik birbiri ile karşıt anlamlar değil birbirlerini tamamlayan ifadelerdir. Bu sebeple özgürlük ve güvenlik ilişkisinin bütünlüğü için güvenlik hizmeti sunan personel ile halk arasındaki ilişkilerin hukuk kuralları içerisinde kalınarak yürütülmesi önem arz etmektedir.

Küreselleşmenin etkisi ile birlikte son yıllarda, güvenlik hizmetlerinin sunumunda, görev tanımlarındaki hizmeti layıkıyla yerine getirmenin yanında, vatandaşların beklenti, istek ve ihtiyaçları doğrultusunda da hareket etmenin gerekliliği vurgulanmaktadır. Bu süreçte güvenlik hizmetlerinin, vatandaşların beklentilerine uyum sağlaması için geliştirilmesi temel beklenti haline gelmiştir. Vatandaşa karşı sorumluluk ve hesap verebilirlik ilkeleri, hizmet sunumunda orantılı güç kullanma yetkisinin şeffaflığını korumaktadır. Güvenlik hizmeti sunumunda, piramit yapının üzerinde bulunan yöneticilerin, kurum içi ilişkilerde ve hizmet sunumunun diğer tarafı olan vatandaşlara karşı tarafsız ve kurum hedeflerini önceleyerek hareket etmesi gerekmektedir. Kamu hizmetinin teknik ustası olarak kabul edilebilecek yöneticilerin, kurumlarında etik davranış ilkelerinin benimsenmesi açısından anahtar rol oynadığını söylemek mümkündür. Çünkü İnsan hak ve özgürlüklerinin korunması için önemli bir işlevi olan güvenlik hizmetinin doğru sunumu noktasında, yasal standartlara uymayan davranışların önlenmesinin yanı sıra etik davranış ilkelerinin benimsenmesi için doğru davranışı vurgulayan bir çalışma ikliminin oluşturulması da gerekmektedir. 


\title{
EXTENDED ABSTRACT
}

\section{Public Services And Professional Policing In the Framework of Social Values}

\author{
Ozan Kavsırac1 \\ Polis Akademisi Başkanlığı
}

The social life where people live together in order consists of a system of values that determine priorities in human behavior and direct behavior. The values system has emerged from the early ages as a result of the discussion of the principles that play a role in determining the right and wrong behavior and distinguishing between good and bad. While people are members of societies, they are also the executors of professional activities, which are an indispensable part of social life. In this regard, values that guide social life and stimulate human behavior play an important role in the execution of professional activities as well. The fact that individuals are involved in the public administration system within the sense of service of the modern state also affects professional principles and values. As a result of this interaction, corporate cultures are shaping up. While corporate values include principles and values that meet the needs of the era, they also aim for employees to adapt to all kinds of innovation and transformation. Thus, possible differences in understanding between the present and future generations will be eliminated. This vision is quite important for the establishment of sustainable security understanding in line with the expectations of citizens in the execution of law enforcement services.

The main purpose in the fulfillment of public services is public interest. The reason for the existence of public administration is the citizens of that country, and the purpose of the public service is to ensure the welfare of the citizens. In this framework, the basic principle that directs the behavior of public officials is public service consciousness. The Weberian bureaucracy, which describes the bureaucratic structure in public institutions, has seen the individuals as machines, essentially expressing the functioning of institutions within the framework of efficiency and effectiveness. 
Weber explained bureaucracy with hierarchy, formalism, division of labor, specialization and order. This structure is insufficient to create a foundation for ethical principles. Because ethical issues in public services are not only limited to legal texts, they also require an analysis of their culture and values. Today, it is necessary to talk about an ideal set of ethical principles in the new public service approach that has been reshaped within the framework of the frequently used governance concept.

In public services along with the new public administration understanding, concepts such as effectiveness, efficiency, frugality and quality have come to the forefront in public services, which are commonly used since the past in private legal entities. The new reforms within the framework of this understanding have made significant changes to the understanding and the practice of accountability in public services. With the spread of the concept of governance since the 1980s, as mentioned above, the perspective of business has started to be effective in public services. In this context, the necessity of ethically sensitive public officials to perform the services in their job descriptions appropriately as well as in accordance with the expectations, demands and needs of the citizens, has begun to be discussed.

As a profession, security services have an important function for the protection of balance in the face of the maximum freedom-security expectations of citizens today. The lack of a static structure of the security approach makes security service and understanding open to the impact of globalization. For this reason, changing living conditions also affect the security service provided. Along with the development of the concept of governance, which is a printout of modern management theory, the security service has also adapted to the qualitative transformation that other public services have experienced. The provision of public order and protecting fundamental rights and freedoms constitute the basis of social life in today's legal states. States carry out security services through law enforcement officers who have been institutionalized and professionally engaged within the scope of ensuring public order.

The element that justifies security measures is that the tools used for the intended purposes are fit for purpose. The burden of security practices 
must be acceptable within the framework of the freedom of society, given that safety is a prerequisite for the freedom of individuals. Law enforcement officers have restrictive authority over the use of fundamental rights and freedoms. In fact, when legal conditions occur, they can even use lethal force in exceptional circumstances. Law enforcement officers are authorized to decide when and how to use these powers. At this point, in order to guarantee fundamental rights and freedoms, it is always necessary to adhere to the rule of law and ethical standards regarding the execution of the service. The principle of accountability towards the citizens maintain the transparency of the authority to use proportional force in the services.

Managers as role models in security service delivery contribute to the social learning process strengthening ethical behavior. However, it is necessary to conduct the management process with ethical principles in order to make managerial decisions in accordance with ethical principles, to resolve possible ethical conflicts and to adopt ethical values by other employees performing security service. It is possible to say that managers who can be considered as the technical masters of the public service play a key role in terms of the adoption of ethical behavior principles in their institutions. Because it is important to create a working climate that emphasizes the right behavior for the adoption of ethical behavior principles, as well as the prevention of behaviors that do not comply with the legal standards, in the correct delivery of the security service, which has an important function for the protection of human rights and freedoms.

\section{Kaynakça / References}

Akarsu, B. (1998). Mutluluk ahlakı. İstanbul: İnkılap kitabevi.

Akdemir, F. (2016). Ahlak m1, etik mi: Etimolojik ve epistemolojik bir çözümleme. Uluğ, F. Ertan, A. K. ve Özgen, H. (ed.), Kamu Etiği Seçilmiş Kongre Bildirileri, Ankara: Türkiye ve Orta Doğu Amme İdaresi Enstitüsü Yayınları, 3-12.

Aktan, C. C. (2009). Ahlak ve ahlak felsefesine giriş, Hukuk ve İktisat Araştırmaları Dergisi, 1(1), 38-59.

Apa, Y. ve Öktem, K. M. (2016). Ahlak m1, etik mi: Etimolojik ve epistemolojik bir çözümleme. Uluğ, F. Ertan, A. K. ve Özgen, H. (ed.), Kamu Etiği Seçilmiş Kongre Bildirileri, Ankara: Türkiye ve Orta Doğu Amme İdaresi Enstitüsü Yayınları, 60-78. 
Aristoteles, (2010). Politika. M. Tunçay, (çev.), İstanbul: Remzi kitabevi yayınları.

Brereton, M. ve Temple, M. (1999). The new public service ethos: An ethical environment for governance. Public Administration, 77(3), 455-474.

Bodur, H. (2017).Etiğin alet çantasına bakmak: Ahlâk, etik ve ilintili temel kavramlar üzerine notlar.Temaşa Erciyes Üniversitesi Felsefe Bölümü Dergisi,7,155-190.

Eryılmaz, B. ve Biricikoğlu, H. (2011). Kamu Yönetiminde Hesap Verebilirlik ve Etik. İş Ahlakı Dergisi, 4(7), 19-45.

Kamu Görevlileri Etik Kurulu, (2015). "2005-2015 Faaliyet Raporu”. http://www.etik.gov.tr adresinden erişilmiştir.

Kamu Görevlileri Etik Kurulu, (2016). "2016 Faaliyet Raporu”, http://www.etik.gov.tr adresinden erişilmiştir

Kamu Görevlileri Etik Kurulu, (2017). “2017 Faaliyet Raporu”, http://www.etik.gov.tr adresinden erişilmiştir

Kavsıracı, O. (2018). Polis faaliyetlerinde gri alanlar ve etik. OPUS Uluslararası Toplum Araştırmaları Dergisi, 9 (16), 1851-1882.

Kolçak, M. (2016). Meslek etiği. Bursa: Ekin Yayınları.

Kutlu, A. H. (2011). "MeslekeEtiği. 1. Basım, Ankara: Nobel akademik Yayıncılık.

Maesschalck, J. (2004). The Impact of New Public Sector Management: The Case Study of Hong Kong. Public Personnel Management, 41(2), 361-378.

Mengüşoğlu, T. (1965). Değişmez değerler değişen davranışlar, Felsefi etik için kritik bir hazırlı, İstanbul: İstanbul Üniversitesi Edebiyat Fakültesi Yayınları.

Önkal, G. Ve Sümer, O. (2016), Etik açısından kamu yararı kavramının olanaksızlığı, Uluğ, F. Ertan, A. K. ve Özgen, H. (ed.), Kamu Etiği Seçilmiş Kongre Bildirileri, Ankara: Türkiye ve Orta Doğu Amme İdaresi Enstitüsü Yayınları, 42-60.

Örselli, E. (2010). Türkiye'de toplumsal ve yönetsel etik değerler ile ikilemler: Uygulamalı bir araştırma. Yayınlanmamış Doktora Tezi, Selçuk Üniversitesi, Sosyal Bilimler Enstitüsü, Konya.

Özgener, Ş. (2018). İş Ahlakının temelleri: Yönetsel bir yaklaşım. Ankara: Nobel yayınları. Özyıldız, S. (2017). Demokratik polislik, teori ve uygulamalar. (1. Baskı), Ankara: Polis Akademisi Yayınları.

Pehlivan, İ. (2002). Yönetsel, mesleki ve örgütsel etik. Ankara: Pegem Yayınları.

Platon, (2011). Devlet. E. S. Cimcöz, A. M. (çev.), İstanbul: Türkiye İş Bankası Kültür Yayınları.

Sökmen, A. (2016). Meslek etiği: Örgütsel ve yönetsel etik:Kurumsal sosyal sorumluluk. Ankara: Detay Yayıncilik.

Stroll, A. A., Long, A. A., Bourke, V. J. ve Campbell, R. (2017). Etik kuramları. Türkeri, M. (der. ve çev.), İstanbul: Lotus yayınları. 
Tekiner, M. A. ve İrdem, İ. (2017). Teoriden uygulamaya güvenlik yönetimi. (1. Basım), Ankara: Polis Akademisi Yayınları.

Türkiye Cumhuriyeti, Kamu Görevlileri Etik Kurulu. (2017). Etik rehberi. Ankara.

Usta, A. (2014). Kuramdan uygulamaya kamu yönetiminde etik ve ahlâk. Kahramanmaraş Sütçü İmam Üniversitesi İktisadi ve İdari Bilimler Fakültesi Dergisi, 1(2), 3950.

Ülgen, H. ve Mirze, S. K. (2004). İşletmelerde stratejik yönetim. İstanbul: Literatür Yayınları.

Yıldırım, M. (2016). Bürokrasi ve tarafsızlık etiği: Eleştirel bir yaklaşım. F. Uluğ, A. K. Ertan, ve H. Özgen, (ed.), Kamu Etiği Seçilmiş Kongre Bildirileri, Ankara: Türkiye ve Orta Doğu Amme İdaresi Enstitüsü Yayınları, 78-90.

Zedner, L. (2015). Güvenlik. D. Orhun, (çev.), Ankara: Polis Akademisi Yayınları.

\section{Kaynakça Bilgisi / Citation Information}

Kavsıracı, O. (2020). Toplumsal değerler çerçevesinde kamu hizmetleri ve profesyonel polislik. OPUS-Uluslararası Toplum Araştırmaları Dergisi, 15(10. Y1l Özel Say1s1), 5308-5337. DOI: 10.26466/opus.721357 